\title{
Determinants of Quality Education Delivery in Selected Public Universities in Ghana: Students' Perceptions
}

\author{
Anthony Akwesi Owusu* \\ University of Cape Coast, Ghana
}

\begin{abstract}
The increased demand for higher education in recent years has thrown into question the issue of quality service. The purpose of this study was to investigate the factors that students perceive as the determinants of quality education service in selected public universities in Ghana. Using a convergent parallel mixed-methods design, data were collected from 606 final year education students for the 2020/2021 academic year while six students were interviewed. From both quantitative and qualitative data, the study found that students perceived their universities to have a high SSR. Also, the quantitative data showed that there is a statistically significant difference in the perceived student-staff ratio scores in the three selected public universities. Finally, the study revealed that students' entry background characteristics such as gender, the programme of study, and age, and institutional factors (such as the personality of the teaching staff, academic factors, administrative systems, and SSR influenced quality education delivery rating (low, or high perceptions) of students. In view of the findings, the study advocated that since the educational enterprise is in competition, public universities should adopt innovative approaches to attract the mass of students wanting to enroll with them in the face of the global educational competition.
\end{abstract}

Keywords: public universities; quality service; student-staff ratio

\section{Introduction}

Education is a basic need for human development (Cheng, 2017) and a key driver for the development of sustainable societies (Stephens et al., 2008). There is increasing evidence that education is positively related to economic growth (Krueger \& Lindahl, 2001). Higher Education Institutions (HEIs) are the ones increasingly acknowledged as key drivers for the development of sustainable societies (Stephens, Hernandez, Roman, Graham \& Scholz, 2008). HEIs are now a 'buyers market' where students buy higher education via the curriculum, faculties, library, resources offered among others. Public universities render

"Corresponding author: Anthony Akwesi Owusu, anthony.owusu@ucc.edu.gh 
account by way of delivery of quality education and providing 'value for money' to justify the colossal public investments of governments in their activities. Universities especially are now considered as service centres with the capacity to target markets based on the standards of quality delivery. Quality education is a broad concept which deals with many variables. Some of the variables include having healthy and well-nourished learners who are ready to learn, and therefore requires the support of their families. Quality also relates to learning in environments that are healthy, safe, protective and gender-sensitive, and provide adequate resources and facilities. Quality measures relevant curricular content accompanied by apt materials for acquiring skills for life and knowledge in areas that promote the development of the country. Quality further denotes processes through which teachers use student-centred teaching approaches in well-managed classrooms with acceptable assessment procedures.

The description of quality education in the manner as has been done conceptualizes education as a complex structure entrenched in a political, cultural and economic context. This paper examined research related to these dimensions of quality. Clearly, quality education is a multifarious concept. Education for All Global Monitoring Report (2014), for example, contended that while all over the world there is a growing agreement about the need to provide access to education of good quality, there is much less agreement about what the term quality actually means in practice. The term "quality education" varies dramatically from country to country depending on cultural and economic priorities. Despite the near-universal agreement as to what cognitive skills comprise, they are not entirely culturally neutral (Education for All Global Monitoring Report, 2014). According to Mwanga (2015), quality education is defined as improving all aspects of the quality of education and ensuring excellence of all so that recognized and measurable learning outcomes can be achieved by all. The marketing literature is replete with the benefits that inure to organisations that are noted for delivering high-quality goods and services to their clients or customers (Potter-Brotman, 1994).

Organisations with relatively higher levels of quality usually reap larger market shares and have reduced costs and increased profit margins (Nwankwo, 2013). In the same way, educational institutions with a demonstrable record of quality tend to attract the best of students to their fold thereby optimizing profit margins. In the education service sector, providing high-quality education services is a sine-qua-non for retaining student and parent customers, and sustaining the organisation's growth (Zameer et al., 2015). Consistently providing a high-quality education service, however, requires institutional managers and practitioners in the sector to manage abundant problems (Zeithaml et al., 1993) that arise from five distinct characteristics of services, not prevalent in physical goods. Education is a highly people-centred enterprise that has students as the simultaneous products who consume the services delivered by institutions.

The determinant is a factor that decisively affects the nature or outcome of something. Good quality education is the one that provides all learners with the 
capabilities they require to become economically productive, develop sustainable livelihoods, contribute to peaceful and democratic societies, and enhance individual well-being (Mwanga, 2015). Recent studies identified the dimensions of quality higher education as quality of students, faculty credentials, academic features, and administrative supports (Akareem \& Hossain, 2012; Sanjay \& Govender, 2018). Schargel (1996) stated that modern universities are experiencing a 'buyers' market' and that students are buying higher education from universities via the curriculum, faculties, library, resources offered, and more importantly SSR analyses among others (Wallisch \& Cachia, 2019). Some studies have shown that the delivery of quality education is determined by multiple measures (Li et al., 2020; Akareem \& Hossain, 2016). Other studies also focused on students' perception of the learning environment across their entire degree and the way these perceptions related to learning outcomes.

Akareem and Hossain (2012) found that students' characteristics, such as current status and socio-economic background influenced the perceptions of quality service in the delivery of education (Clemes et al., 2001; Sanjay \& Govender, 2018).Some studies, identifying multiple measures, focused on student quality, faculty credentials, academic features, SSR, and administrative supports as benchmarks for determining quality in higher education delivery (Akareem\& Hossain, 2012). They noted that the socio-economic background variables of students influence their perception of higher education quality. Conceptually, the student entry variables and the institutional factors constitute the perceived determinants of quality. Figure1 illustrates a hypothesized conceptual framework of the study.

Determinants of quality delivery

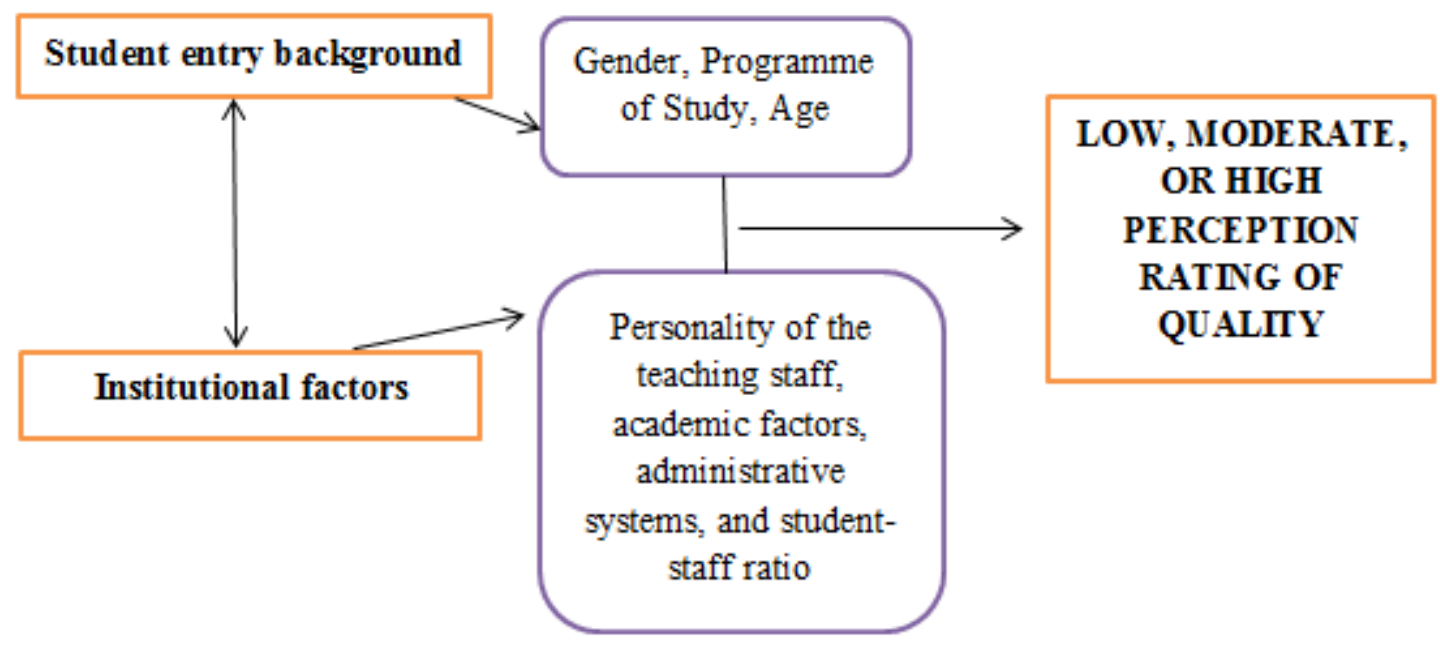

Figure 1: A theorized conceptual framework of the study

\subsection{The Research Problem}

Evidence has shown that there is a surge in the demand for higher education in most societies giving meaning to the proliferation of private higher education institutions. According to Labi (2007), higher-education systems around the 
world have experienced and continue to experience inconceivable growth in recent years. The phenomenon has been described as an unprecedented global academic revolution. Unfortunately, the growth is not commensurate with the infrastructural development of many of these institutions. As a result, many public universities are facing acute infrastructural deficits thereby, watering down quality. Many of these institutions have unimaginable high student-staff ratios with poor and over-stretched infrastructure (Andrews (2019).

Despite the surging numbers of enrollment worldwide, fundamental questions to ensure the quality and accessibility of higher education remain very paramount. The increase in demand for higher education arises from a variety of sources: rising aspirations, changing employment patterns, changing careers, rising incomes, and wealth beyond a high school education a growing necessity for a number of students (Sá, 2019). The general perception of society has shown that a more educated population is regarded as a vital investment for societies and economies. Many of the students patronize government-sponsored universities. However, in the face of scarce economic resources, government support for these public institutions has drastically declined. In Ghana, the situation is so dire that the government is advocating for cost-sharing in tertiary education. The situation has resulted in stiff competition arising from private participation in the provision of tertiary education. The competition that public universities face relate to their appeal to the public on the degree to which they provide quality education.

\section{Literature Review}

The perceptions people have about the quality that a particular public university delivers seems to drive students to enroll in those universities. Therefore, university profiles or images are contingent partly on the perception of quality that students derive by attending those institutions (Rahman, 2013). In this sense, it is clear that quality relates to institutional profiling and HEIs need to understand the importance of creating an attractive image to attract a body of loyal customers (Akareem \& Hossain, 2016). If students hold the perception that an institution provides poor services to their clients, they deliberately blacklist those institutions by not patronizing them or even advising friends and relatives to do so. Eventually, bad perceptions reduce the profile of the institutions thereby, affecting their public image and reducing public confidence in them. Such institutions are unable to attract the required number of students to enhance their financial status in the time of declining government financial support. Such universities fail to attract the required numbers of students who enroll there to pursue their programmes.

On the other hand, if students hold good perceptions about an institution, those perceptions tend to attract the many people who desire to demand higher education. If government support to public universities is dwindling at a time when these public institutions are also competing with private universities in the supply of university education, quality becomes a critical issue that 'buyers' (students) consider to decide where to enroll and access tertiary education. A study of this kind, therefore, becomes crucial since it provides an opportunity to 
ascertain students' perceptions of quality service delivery (Sanjay \& Govender, 2018). Based on the perceptions, the universities could put in place quality assurance mechanisms to address some of their challenges that often fuel the negative perceptions among students, and which usually tend to be inimical to the image of public universities. In Ghana, studies on this subject remain largely unexplored hence, the motivation to carry out this study.

This study, therefore, seeks to fill the knowledge gap by investigating students' perceived determinants of quality education delivery in public universities in Ghana. To do this, their perceptions of quality (Clemes, Ozanne \& Tram, 2001; Gallifa \& Batallé, 2010) delivery in relation to students' entry background characteristics (gender, programme of study, and age), the personality of the teaching staff, academic factors in the universities, administrative systems, and SSR will be investigated and explained in the context of three public universities in Ghana.

\subsection{Objective(s) of the Study}

The study sought to investigate the determinants of quality education in three public universities (UCC, UEW, and UG) in Ghana as perceived by students. Specifically, the study seeks to achieve the following objectives:

- Describe students' perceptions of the SSR in their institutions;

- Examine whether there is a statistically significant difference in the perceived student-staff ratio scores in the three participating universities; and

- Investigate whether students' entry background characteristics (gender, programme of study, and age), institutional factors such as the personality of the teaching staff, academic factors, administrative systems, and SSR affect their low, moderate, or high perceptions of quality education delivery.

\subsection{Significance of the Study}

The findings of this study are significant to many stakeholders in higher education management. For instance, to policymakers, university managers, faculty members, students, parents, and stakeholders may get to know the determinants of quality service to help them formulate appropriate policies to address the challenges related to quality service delivery to students. This is because higher education institutions already appear to face greater fears from students, parents, employers and taxpayers who demand accountability from them for teaching service quality. Therefore, the outcome of this study may help public institutions be able to respond to the growing demand for meaningful and relevant education. Also, the study provides insight into to university academic boards to come out with quality teaching and learning policies to improve teaching services in our public universities. The study shares useful information to authorities of public universities on steps they need to take to enhance learning conditions of students in universities.

The Ghana Tertiary Education Policy of the Ministry of Education document (GTEP, 2019, p. 51) urged that: "the Regulator shall from time to time develop and implement norms ... for various programmes and institutions in 
consultation with the Ministry of Education". A study of this kind provides feedback to the government as to the extent to which institutions of higher learning, particularly public ones are implementing the doctrines as enshrined in the national document. Further, the study may furnish the government with relevant information for policy formulation and implementation to improve quality education delivery in public universities in Ghana. In addition, the findings provide an up-to-date solution to student concerns in relation to quality education delivery. Finally, the results provide useful data to the National Accreditation Board (NAB) and other government agencies responsible for regulating activities in public universities.

\section{Methodology}

The study seeks to investigate the determinants of quality education in three public universities (UCC, UEW, and UG) in Ghana as perceived by students.

\subsection{Study Design}

I used a convergent parallel mixed-methods design for the purpose of triangulation. In this design, the quantitative and qualitative strands of the research are performed independently, and their results are brought together in the overall interpretation (Bryman, 2006). For parallels design, one has two or more parallel quantitative and qualitative elements; either with some minimal time-lapse or concurrently; the strand results are integrated into meta-inferences after distinct analysis is conducted. It relates to QUAN and QUAL research questions that are answered or aspects of the same mixed research question which are addressed (Guetterman, 2020). The main reason for the use of triangulation is based on the principle that no single method ever is sufficient to solve a particular problem (Denzin, 1999; Guetterman, 2020). Furthermore, using only one method is susceptible to error associated with that particular method. Therefore, the use of multiple methods to study the same phenomenon should lead to greater validity and reliability than a single method. When different methods are used, the inherent bias in that particular method is neutralized with the introduction of the other methods. Besides, since every method has its own merits and demerits, the multiplicity of methods strengthens any weakness identified with one and thus, becomes helpful.

\subsection{Population}

The population of the study consisted of 3,720 final year Level 400 education students in the University of Cape Coast (UCC), University of Education, Winneba (UEW), and University of Ghana (UG) for the 2020/2021 academic year. Only Level 400 students were considered because they were deemed to have spent many years in school and were therefore abreast of the many issues on quality assurance determinants in their respective institutions. They were approximately 1,908 (51.3\%) male and 1,812 (48.7\%) females, according to the figures for the 2019/2020 academic year for the selected traditional universities pursuing various bachelors of education (Bed.) degree programmes in different subject areas. 


\subsection{Sample and Data Collection}

The sample size for this study was 606 which was made up $16.3 \%$ of the 3,720 final year Level 400 students in the population. $16.3 \%$ of students was representative enough of the number of students in the population. However, Martino et al. (2017) recommended oversampling especially for online surveys. They argued that since many educational and social research studies, like this one, use survey data collection and other voluntary participation methods response rates are usually typically below $100 \%$. Therefore, If you are mailing out surveys or questionnaires, . . count on increasing your sample size by $40 \%$ $50 \%$ to account for lost mail and uncooperative subjects (Martino et al., 2017). In line with this thinking, I added 54 to the minimum sample size, thus bringing the number to 660. I used a stratified random sampling technique which is a technique that requires the population to be put into smaller groups, called strata. The choice of this technique ensured that specific groups of students were represented in the final sample. The final sample size for this study was 660 final year education students, consisting of $17.7 \%$ of the students in the population. To get the sample, I constructed a sampling frame that comprised the 3,720 education students $(\mathrm{N})$ in the three universities.

Since I was interested in both male and female university students, gender (male/female) was the stratification variable. With the assistance of the Student Records section, I obtained the list of all males and females students studying education in the universities. Secondly, I assigned a consecutive number to each of the students in each stratum, and therefore I ended up with two lists: one for all males and one for female students in a disproportionate manner. I then used a simple random technique to select the final samples for the study. I used purposive sampling to pick six students for the interviews. To avoid any possible biases, these students were not among those whom the questionnaires were administered to. This approach ensured that their views corroborate those responses on the questionnaire by their mates.

\subsection{Research Instruments}

Two research instruments (questionnaire and an interview schedule) were used to collect data in this study. The questionnaire was divided into three sections: A, B, and C with closed-ended questions. The first section contained items related to respondents' profile with four items (the university, the programme of study, gender, and age). The second section contained eight questions on the learning context of students (student-staff ratio, teacher personality, and academic factors in the university) measured on a three-point scale. A total of 23 items consisted of the third section, which focused on students' perceptions of quality education delivery (Clemes et al., 2001). These perceptive items were measured on a 9-point scale and were afterwards translated into three responses based on higher, moderate, and lower student expectation (Akareema \& Hossain, 2016). The interview schedule comprised of 12 items that elicited responses on perceptions regarding quality delivery in their respective universities. The items on the guide were probed to gain more insight and also to see if the responses of the questionnaire corroborated by the interviews data. 
To ensure data credibility, I took measures to boost the credibility, transferability, dependability, flexibility, and confirmability of the study.

\subsection{Quality Assurance and Ethical Issues}

Quality assurance and adherence to ethical considerations are critical to ensuring effective research and cogent outcomes. In line with the rules and regulations of research involving human subjects, I took the following ethical issues very seriously during the course of the study (Sayer, 2011). The research activity must be conducted in a way that assures no ethical breaches. In line with this, the participants were given the freedom to decide whether they wanted to be involved and also ensured that none of them was exposed to any harm. I considered a range of issues including permission to conduct the study, confidentiality and privacy, voluntary participation, and informed consent. I obtained a written ethical clearance from the Institutional Review Board (IRB) to conduct this research. With the ethical clearance and a formal written permission letter, I went to the various campuses to deliver them and request their support at the Registrar's office. I then waited for a formal response and once that was received, I began the actual process. I assured respondents of confidentiality and anonymity by hiding their real identities with pseudonyms. I also ensured a cordial but professional relationship between me and the respondents (Akareema \& Hossain, 2016). Respondents were asked to refuse any question they deemed inappropriate or sensitive to answer.

\subsection{Data Collection Procedures}

Prior to the collection of data, respondents' consents were sought. I explained the rationale of the study to them and sought their cooperation. The questionnaires were distributed to the students by the researcher with the help of an assistant. The assistant was schooled on the rationale for the study and the need to ensure that the necessary research protocols are strictly complied with. I, together with the research assistant took students through each item thoroughly and explained issues to them to guard against ambiguity in subjects' responses. This method was also to help reduce the invalid responses and the fatigue often associated with survey data collection. Both data, whose collection lasted for three weeks, were collected concurrently. Due to the surging numbers of Covid19 cases and the accompanying restrictions on face-to-face activities, some of the questionnaires were administered online though the interviews were conducted face-to-face (Understanding Research Interviews [URI], 2015). Before the collection of actual data, I conducted a pilot-testing to establish the internal consistency of the items on the instrument. I did this on 30 students in an analogous university with similar characteristics as that of the research setting. A Cronbach alpha reliability coefficient of 0.789 was obtained and deemed good and indicative that the items on the instrument were internally cohesive.

\subsection{Analysis of Data}

Descriptive analyses, one-way factorial ANOVA, and binary logistic regression were used. The binary logistic regression was used to examine the association between the criterion (higher and lower perception of quality) and the predictor variables (entry background characteristics: gender, the programme of study, and age) (environmental factors: the personality of teaching staff, academic 
factors, administrative systems, and SSR). For the qualitative data, thematic analysis was used which is a method for methodically identifying, organising, and offering insight into patterns of meaning (themes) across a dataset (Clarke \& Braun, 2014). I used the six-phase approach to thematic analysis which they outlined. These phases included familiarizing with the data, generating initial codes, searching for themes, reviewing potential themes, defining and naming themes, and finally producing the report

\section{Results}

The return rate for the questionnaire was $91.5 \%$ since 606 out of the 660 respondents completed and returned the survey instruments. They comprised overall, 299 females and 307 males. The study examined students' perceptions of the determinants of quality education delivery in three public universities in Ghana. Table 1 provides the profile of the respondents who were surveyed in the study.

Table 1. Distribution of demographic information of participants

\begin{tabular}{|c|c|c|c|c|}
\hline $\begin{array}{c}\text { Demographic Variables } \\
\text { Programme }\end{array}$ & UCC & EUW & 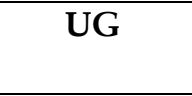 & Total \\
\hline Bed. Soc. Sci. & 41 (12.6.) & $142(72.4)$ & $0(0.0)$ & $183(30.2)$ \\
\hline Bed. Business & $197(60.6)$ & $8(4.1)$ & $3(3.5)$ & $208(34.0)$ \\
\hline Bed. Arts & 38 (11.7) & 33 (16.8) & $1(1.2)$ & 72 (11.9) \\
\hline Other & 49 (15.1) & $13(6.6)$ & $81(95.3)$ & 143(23.6) \\
\hline Total & $325(53.6)$ & $196(32.3)$ & 85 (14.026) & $606(100)$ \\
\hline \multicolumn{5}{|l|}{ Gender } \\
\hline Female & $200(61.5)$ & $91(46.4)$ & $8(9.4)$ & $299(49.3)$ \\
\hline Male & $125(38.5)$ & 105 (53.6) & 77 (22.7) & 307 (50.7) \\
\hline Total & 325 (53.6) & $196(32.3)$ & 85 (14.026) & $606(100)$ \\
\hline \multicolumn{5}{|l|}{ Age } \\
\hline $12-22$ years & $125(38.5)$ & 105 (53.6) & 43 (50.6) & $273(45.06)$ \\
\hline 23 - 33 years & $200(61.5)$ & $91(46.4)$ & $40(47.1)$ & $331(54.6)$ \\
\hline 34 above & $0(0.0)$ & $2(2.4)$ & $0(0.0)$ & $2(0.34)$ \\
\hline Total & $325(53.6)$ & $196(32.3)$ & 85 (14.026) & $606(100)$ \\
\hline
\end{tabular}

Table 1 shows that there is a gender gap in the various fields of study in the participating universities and a relatively young age distribution of respondents represented though many of the respondents above 34 years came from UEW. For the interviews, I picked six students (three males and three females), two from each institution. I gave the interviewees pseudonyms (UCCM/UCCF; UEWM/UEWF; UGM/UGF) in consonance with research anonymity doctrine. I used the deviant case purposive sampling to pick the students in order to obtain different perspectives of students on the issue the students were of the average age of 24 years and final year students pursuing programmes in the humanities, arts, business and the social sciences. The profile divulges the capacity of the respondents to provide necessary responses in answer to all the germane questions of the study. 


\section{Research Question}

What are students' perceptions of the SSR in their institutions?

To answer this question, I used simple descriptive statistics as shown in Table 2. The results showed that a majority of the students $560(81.3 \%)$ described the student-staff ratio as high (81:1 and above). However, $46(6.7 \%)$ of them also responded that the student-staff ratio in their university was low, consisting of between 28 students and 80 is to one staff. A cross-tabulation of the universities and the student-staff ratio descriptions revealed that in UCC 41 of the students described the student-staff ratio as low, whereas 284 described it as high (81 and above). In UEW, 142 described it as low while 54 felt it to be high. In UG, 28 were of the opinion that the student-staff ratio was low meanwhile 57 responded that the student-staff ratio was high. Clearly, the majority 395 (65.2\%) described the ratio as high while 211(34.8\%) felt otherwise.

Table 2. Cross tabulation of University and Description of Student-staff ratio

\begin{tabular}{|c|c|c|c|c|c|c|c|c|c|c|c|}
\hline Univ. & \multicolumn{3}{|c|}{ UCC } & \multicolumn{3}{|c|}{ UEW } & \multicolumn{3}{|c|}{ UG } & \multicolumn{2}{|c|}{ Total } \\
\hline $\begin{array}{l}\text { Student-staff } \\
\text { ratio }\end{array}$ & $n$ & $\mathrm{M}$ & SD & $n$ & $\mathrm{M}$ & SD & $n$ & $\mathrm{M}$ & SD & $\mathrm{M}$ & SD \\
\hline Low (28-80:1) & 41 & 7.55 & 1.82 & 142 & 7.77 & 1.81 & 28 & 6.50 & .57 & 7.27 & 1.40 \\
\hline $\begin{array}{l}\text { High (81:1 and } \\
\text { above) }\end{array}$ & 284 & 7.90 & 1.45 & 54 & 8.75 & .71 & 57 & 8.89 & .50 & 8.51 & .88 \\
\hline Total & 325 & 7.94 & 1.71 & 196 & 8.10 & 1.67 & 85 & 8.08 & 1.26 & 8.04 & 1.55 \\
\hline
\end{tabular}

The qualitative data from the interview also corroborated the findings of the quantitative data. The interviewees were asked to express their opinions about the student-staff ratio in the various institutions. The majority held the view that the student-staff ratio in their institutions was high. For instance, one noted that "The student number, compared to the staff is high; I think it is very high in my department" [UCCM]; "...so very high, I think" [UCCF]; ..." high because sometimes the same lecturer will be handling four or even more courses; personally, I feel it is too much for such lecturers" [UEWF]. Others also intimated that "...the student-staff ratio in my university is high that's why some of the lecturer theatres operate with public-address systems [UEWM]. Clearly, the theme that emerged was the high student-staff ratio. The two data sets pointed to the same theme implying a commonality in the quantitative and qualitative finding.

\section{Hypothesis 1}

$\mathrm{H}_{1}$ : Students' perceptions of the student-staff ratio vary significantly depending on the programme they offer across the three universities.

To test this hypothesis, a two-way factorial ANOVA test was conducted to examine whether significant differences exist in the respondents' perceptions of the student-staff ratio scores in the three participating universities as illustrated in Table 3. 
Table 3. Two way analysis of variance for student-staff ratio as a function of programme of study and university

\begin{tabular}{|c|c|c|c|c|c|}
\hline Variable source & $D f$ & Mean Square & $F$ & Sig. & $\eta^{2}$ \\
\hline \multicolumn{6}{|c|}{ Perceived student-staff ratio } \\
\hline University & 2 & 14.460 & $6.169^{* *}$ & .002 & .020 \\
\hline Programme of study & 3 & 23.095 & $9.853^{* *}$ & .000 & .047 \\
\hline University*Programme & 6 & 12.053 & $5.142^{* *}$ & .000 & .049 \\
\hline Error & 593 & 2.344 & & & \\
\hline
\end{tabular}

${ }^{*} \mathrm{p}<.005,{ }^{* *} p<.001$

Table 4. Mean, standard deviations, and $\mathbf{n}$ for student-staff ratio as a function of programme and university

\begin{tabular}{|c|c|c|c|c|c|c|c|c|c|c|c|}
\hline Univ. & \multicolumn{3}{|c|}{ UCC } & \multicolumn{3}{|c|}{ UEW } & \multicolumn{3}{|c|}{ UG } & \multicolumn{2}{|c|}{ Total } \\
\hline $\begin{array}{l}\text { Programme of } \\
\text { study }\end{array}$ & $n$ & $\mathrm{M}$ & SD & $n$ & $\mathrm{M}$ & SD & $n$ & $\mathrm{M}$ & SD & $\mathrm{M}$ & SD \\
\hline BEd, Soc. Sci. & 41 & 7.55 & 1.82 & 142 & 7.77 & 1.81 & 24 & 6.50 & .57 & 7.27 & 1.40 \\
\hline BEd. Business & 197 & 7.90 & 1.45 & 8 & 8.75 & .71 & 57 & 8.89 & .50 & 8.51 & .88 \\
\hline BEd. Arts & 38 & 9.05 & .20 & 33 & 9.20 & .46 & 1 & 7.00 & - & 8.42 & .33 \\
\hline Other & 49 & 7.60 & 2.68 & 13 & 8.62 & .74 & 3 & 5.83 & .76 & 7.35 & 1.39 \\
\hline Total & 325 & 7.94 & 1.71 & 196 & 8.10 & 1.67 & 85 & 8.08 & 1.26 & 8.04 & 1.55 \\
\hline
\end{tabular}

Table 4 shows the number of subjects, the mean and standard deviation of the perceived student-staff ratio for each cell. Simple effect analyses revealed that students pursuing all three programmes (including the 'other' programme) in the University of Education, Winneba (UEW) had perceptions of high studentstaff ratio than students from UCC and UG did. Also, students pursuing all the programmes in UCC had perceptions of high student-staff ratio than students of UG did. The table presents the findings of the factorial ANOVA. We can see that the model is statistically significant $(F(6,593)=5.142, p=.001)$, indeed the Partial Eta Squared suggests that programme of study, sex and age accounted for $4.9 \%$ of the variance in students' perception of the student-staff ratio in this model. That said, the Partial Eta Squared for university is $2.8 \%$ and the programme of study is $4.7 \%$.

The interview revealed that the perception of the student-staff ratio depends on the university and the programme of study. It became obvious that the studentstaff ratio differs from programme to programme and not a straitjacket that in all programmes, the ratio is high. For instance, the response of one student was that "The student-staff ratio is high in my programme and the student population is increasing by each year" [UGF]. Attesting to this fact is the issue of the number of enrolments in their respective programmes of study. When they were asked to give their opinion about the number of people enrolled in their programmes, some said, "I think it's ok [UEWM]; others said, "The number is sizeable enough [UEWF], and for some, "...increasing number of students; no place to put your bag [mpo] ... and I feel something must be done about it [UGM]. The results from the two datasets showed that the qualitative data corroborated the findings of the quantitative data. 
Hypothesis 2

$\mathrm{H}_{1}$ : The combination of entry background characteristics (gender, programme of study, and age), and institutional factors (university, personality of the teaching staff, academic factors, administrative systems, and SSR significantly predict students' low or high perception of quality education.

To test hypothesis 2, a logistic regression was used to examine the effects of the combination of student entry background characteristics (gender, programme of study, age), institutional factors (university, the personality of the teaching staff, (academic factors), administrative systems, and SSR on students' perceptions (low or high) of quality education. The logistic regression model was statistically significant, $\chi^{2}(10)=127.078, p<.005$. The model explained 28.3\% (Nagelkerke $\mathrm{R}^{2}$ ) of the variance in student perceptions of quality education. The statistical significance of the test is found in the "Sig." column of Table 2.

From Table 1, 460 students had a low perception rating of quality while 146 had a high perception of quality education (Rahman, 2013). Thus, if one simply guessed that no student had low perceptions of quality education, one would classify $75.9 \%$ of the students correctly by chance. Gender, age, flexible in giving marks (personality of the teaching staff), student evaluation system (academic factor), admission procedures (academic factor), curricular design and planning with up-to-date information (academic factor), and job prospects (academic factor) are each separately significantly related to students' low or high perceptions of quality education delivery. The overall model is significant when all seven (7) independent variables are entered. The Cox and Snell $\mathrm{R}$ square value of $18.9 \%$ and the Negekerte R square of $28.3 \%$ which are similar to R2 give a rough estimate of the variance that can be predicted from the combination of the predictor variables. It is clear that $98.3 \%$ of students who had a low perception rating of quality education delivery were predicted correctly with this model, but $28.8 \%$ of those who had a high perception rating of quality delivery of education were predicted correctly.

The university of the student, their programme of study, gender, age teacher personality (flexible in giving marks), and academic factor (admission procedure) but not boring, egoistic, and compassionate teaching staff, research output (academic factor, student evaluation system (academic factor), and curricular design and planning with up-to-date information (academic factor) are significant predictors when all seven independent variables are considered together. This suggests some correlation among predictors since teacher personality type (boring, egoistic, and compassionate) and research output level of teaching staff (academic factor) were significant predictors when used alone. But, student evaluation system (academic factor), and curricular design and planning with up-to-date information failed to predict low or high perception rating of quality education delivery when used alone or with other variables. 
Table 5. Binary logistic regression results on the effects of predictors on low or high perception of quality education service.

\begin{tabular}{|c|c|c|c|c|c|c|}
\hline Variables & $\beta$ & SE & Wald & Sig & $\begin{array}{l}\text { Odds } \\
\text { ratio }\end{array}$ & $95 \%$ CI \\
\hline University & -.468 & .202 & 5.336 & .021 & .627 & $.421-.932$ \\
\hline Programme of study & -.736 & .172 & 18.410 & .000 & .479 & $.342-.670$ \\
\hline Gender & -1.777 & .531 & 11.221 & .001 & .169 & $.060-.478$ \\
\hline Age & 1.047 & .477 & 4.809 & .028 & 2.848 & $1.118-7.259$ \\
\hline $\begin{array}{l}\text { Teacher personality (boring, } \\
\text { egoistic, and compassionate) }\end{array}$ & -.859 & .467 & 3.380 & .066 & .424 & $.170-1.058$ \\
\hline $\begin{array}{l}\text { Research output of teaching } \\
\text { staff (academic factor) }\end{array}$ & .638 & .452 & 1.992 & .158 & 1.893 & $.780-4.591$ \\
\hline $\begin{array}{l}\text { Flexible in giving marks } \\
\text { (teacher personality) }\end{array}$ & -5.034 & 1.083 & 21.607 & .000 & .007 & $.001-.054$ \\
\hline $\begin{array}{l}\text { Evaluation systems for } \\
\text { quizzes, exams, assignments } \\
\text { etc. (academic factor) }\end{array}$ & 20.031 & 16161.693 & .000 & .999 & $\begin{array}{l}5005359 \\
28.914\end{array}$ & $.000-$ \\
\hline $\begin{array}{l}\text { Admission procedure } \\
\text { (academic factor) }\end{array}$ & 2.684 & .395 & 46.204 & .000 & 14.643 & $6.753-31.748$ \\
\hline $\begin{array}{l}\text { Curricular design and } \\
\text { planning with up-to-date } \\
\text { information (academic } \\
\text { factor) }\end{array}$ & 6.028 & 19818.787 & .000 & 1.000 & 414.704 & .000 \\
\hline Constant & -42.89 & 22942.122 & .000 & .999 & .000 & \\
\hline
\end{tabular}

Table 5 reflects the results in which one sees university $(p=021)$, programme of study $(p=.001)$, gender $(p=.001)$, age $(p=.028)$, flexible in giving marks $(p=$ $.001)$, evaluation systems for quizzes, assignments etc, $(p=.001)$, and admission procedure $(p=.001)$ have added significance to the model/prediction, but personality of teaching staff $(p=.066)$, research output of teaching staff ( $p=.158$ ), evaluation systems for quizzes, exams, assignments etc. (.999), and curricular design and planning with up-to-date information $(p=1.00)$ did not add significance to the model. When all predictor variables are considered together, they significantly predict whether or not a student had high or low perceptions of quality education, $x^{2}=127.078, \mathrm{df}=10, \mathrm{~N}=606, p=<.005$. The odd ratios or the $\operatorname{Exp}(B)$ value, if it is greater than one, denotes a positive association implying higher number for the predictor means group one in the outcome, whereas an odds ratio less than one denotes a negative association meaning a higher number for the predictor means group zero in the outcome. The odds ratio and the confidence interval for university was .627 $(.95 \% \mathrm{CI}=421-.932)$, programme of study was $.479(.95 \% \mathrm{CI}=4.342-.670)$, gender was $(.95 \% \mathrm{CI}=.060-.478)$, age was $3.848(.95 \% \mathrm{CI}=1.118-7.259)$, flexible in giving marks was $.007(.95 \% \mathrm{CI}=$ $.001-.054)$, and admission procedure yielded $14.643(.95 \% \mathrm{CI}=6.753-31.748)$

From Table 2, the odds ratio, which suggests that the odds of estimating correctly that a student has high perceptions of quality education reduced by $62.7 \%$ from one university to the other while their high perceptions of quality 
education reduced by $47.9 \%$ depending on a student's programme of the study area. Again, the odds of estimating correctly that a student has high perceptions of quality education reduced by $16.9 \%$ depending on the gender of the student while high perceptions of quality education increased by $84.8 \%$ depending on the age of the student. Additionally, the data showed that the odds of estimating correctly that a student has high perceptions of quality education reduces by $0.7 \%$ depending on what students think about their teachers' flexibility in giving marks, meanwhile their high perceptions of quality education increased by $91.4 \%$ depending on what they think about the evaluation systems in their respective universities. Finally, the data uncovered that the odds of estimating correctly that a student has high perceptions of quality education improved by $70.4 \%$ if one knows the admission procedures that exist in a university.

The interview questions on this subject basically required the interviewees to state whether, in their estimation, the entry background characteristics (gender, programme of study, and age), and institutional factors in their university, the personality of the teaching staff, academic factors, administrative systems in their universities, and the SSR in their universities influence their low or high perceptions of quality education. The respondents' views which came up as themes on the matter were not dissenting. Many of them pointed out that the entry background of entrants is a basis for perceiving a university to deliver quality. These sentiments were expressed in the following statements, "It may not be true but there is a notion that universities noted not for quality tend to admit older students. I don't think I agree because this may not have any scientific basis" [UGM]; "Some programmes are not seen to be important because of public perceptions and so high numbers into those programmes evokes a certain sense of no quality [UEWF].

Others also stated that the personality of the teaching staff and their capacity to teach is an index for perceiving a university to be providing quality. They explained that the quality of staff guarantees quality tuition and thus feeds into the perception of high quality. However, many said that gender cannot influence or be a yardstick for perceiving an institution to deliver quality. They are unanimous that effective administrative structures in universities and the state of the student-staff ratio are benchmarks for measuring quality. For instance, one said, "Quality can be assured when the administrative structures and systems in the university are allowed to work" [UCCM]. Another interviewee said, "We cannot talk about quality if the student-staff ratio is high; that indicates a deficit in resources" [EUWF]. The results here also clearly validate the quantitative findings wherein background characteristics of students and institutional factors influence high or low student perceptions of quality education.

\section{Discussions}

High student-staff ratio is almost a common feature among many universities including public universities (Ngoc \& Hawkins, 2018). The phenomenon is characterized by a system where student enrolments outstrip the necessary available resources in the delivery of education service. The situation in many 
Ghanaian universities has been exacerbated by the increasing demand for public education (Sá, 2019). In a bid to improve the quality of its human capital, governments resort to encouraging their citizens to patronize tertiary education without a conscious corresponding governmental effort to ensure improvement in infrastructure. Many public universities today are saddled with large student enrolments without commensurate improvements, thereby reducing quality delivery (Sá, 2019). The phenomenon of high student-staff ratio creates perceptions of low quality which is injurious to the profile of public universities both internally and externally (Andrews, 2019). Also, the student background characteristics such as gender, age, the programme of study, the type of institution or university, the personality of the teaching staff, academic factors, administrative systems, and SSR affect student perceptions of quality education (Gallifa \&Batallé, 2010).

Clearly, the findings of this study concurred with other studies in earlier ones. For instance, this study has shown that quality delivery is determined by many indices. This outcome agreed with an earlier study by Akareem and Hossain (2016) which also showed that delivery of quality education (as is perceived) is determined by several measures. Again, the findings of this study also matched with the ones by Akareem and Hossain (2012) and Total Quality Management in Education (2020) who found that perceptions of quality in higher education institutions are influenced by faculty credentials, academic features, and administrative support structures among others. Besides, Akareem and Hossain (2012) , however, found that current status and socio-economic background as student characteristic factors influenced perceptions of quality education (Kulik et al., 2019). In addition, this study concluded that faculty credentials, academic features, and student-staff ratio (Wallisch\& Cachia, 2019) as factors that influenced students' perceptions of quality education service concurred with the study of Akareem and Hossain (2012).

\section{Conclusion}

Based on the analysis and discussions, it is safe to conclude that there are differences in the perceived student-staff ratio among students from one public university to the other. As seen in the case of the three participating public universities, students' entry background characteristics such as gender, the programme of study, and age, and institutional factors influence perceptions of quality service among students. It therefore behooves public universities to adopt more pre-emptive and entrepreneurial approaches to market their quality services to their global constituencies.

In view of the findings, the following recommendations and considerations are addressed to all stakeholders in high education delivery in Ghana:

i. It is recommended among other things that the government should put in an effort to resource public universities with both human and material resources to make them deliver quality service to students. This could also help them deliver on their mandate go a long way to reduce the perceptions students have of the student-staff ratio. 
ii. The study showed that the personality of teaching staff and administrative services are critical in the formation of student perception of quality. Therefore, the management of public universities should play roles that leave indelible pleasant memories about their institutions. These memories engender positive student perception of quality educational experiences. They should use human resource strategies that align with market-orientated management strategies by giving due recognition to staff as a critical resource.

iii. Since the study established that students' perceptions of service quality differed significantly from institution to institution, from programmes of study to programme of study, and from age to age, public university managers should leverage the discriminating factors by first identifying them and creating appropriate strategies to achieve specific targets.

iv. Since it was clear that the educational institutions are in competition, public universities should do all within their power to use state-of-the-art strategies to make them competitive and attractive to students.

\section{Limitations}

This study relied on samples from only three public universities and views from these institutions may not represent the general perceptions of the student population in Ghana. Also, the differences in the sample size in the three universities could account for the differences in the statistical significance of the results. This can adversely affect the inferences and conclusions drawn on the results.

\section{Acknowledgement}

I am greatly indebted to all participants of this study. I would like also to thank the Institutional Review Board of the University of Cape Coast (IRB, UCC) for the proposed protocols and input which refined the outlook of the study. Also, I want to thank the Directorate of Research Innovation and Consultancy (DRIC, UCC), Ghana for accepting to fund this study. In fact, the directorate gave full funding in the individual-led research category for the 2021-2022 academic year. I state, however, that any flaws in this study remain solely mine.

\section{References}

Akareem, H. S., \& Hossain, S. S. (2016). Determinants of education quality: What makes students' perception different? Open Review of Educational Research,3(1), 52-67. https://doi.org/10.1080/23265507.2016.1155167

Akareem, H. S., \& Hossain, S. S. (2012). Perception of education quality in private universities of Bangladesh: A study from students' perspective. Journal of Marketing for Higher Education, 22(1), 11-33. https://doi.org/10.1080/08841241.2016.705792

Andrews, A. (2019). Revisiting the staff to student ratio outcomes of the HOCS Survey 2018. The Journal of the Australian and New Zealand Student Services Association, 27(2), 224-230. https:// doi.org/10.30688/janzssa.2019.12

Bryman, A. (2006). Integrating quantitative and qualitative research: How is it done? Qualitative Research, 6, 97-113. https://doi.org/10.1177/1468794106058877

Cheng, M. (2017). Reclaiming quality in higher education: A human factor approach. Quality in Higher Education, 23(2), 153-167. https:// doi.org/10.1080/13538322.2017.1358954 
Clarke, V., \& Braun, V. (2014). Thematic analysis. Encyclopedia of Critical Psychology, 1947-1952. https://doi.org/10.1007/978-1-4614-5583-7_311

Clemes, M. D., Ozanne, L. K., \& Tram, L. (2001). An examination of students' perceptions of service quality in higher education. Journal of Marketing for Higher Education, 10(3), 1-20. https://doi.org/10.1300/J050v10n03_01

Denzin, N. K. (1999). Biographical research methods. Issues in Educational Research, 92102. https://doi.org/10.1016/b978-008043349-3/50009-8

Education for All Global Monitoring Report. (2014). Encyclopedia of Quality of Life and Well-Being Research, 1811-1814. https://doi.org/10.1007/978-94-007-0753-5_3082

Gallifa, J., \& Batallé, P. (2010). Student perceptions of service quality in a multi-campus higher education system in Spain. Quality Assurance in Education, 18(2), 156-170. https://doi.org/10.1108/09684881011035367

Guetterman, T. C. (2020). Qualitative, quantitative, and mixed methods research sampling strategies. education. https://doi.org/10.1093/obo/9780199756810-0241

Krueger, A. B., \& Lindahl, M. (2001). Education for growth: Why and for whom? Journal of Economic Literature, 39(4), 1101-1136. https:// doi.org/10.1257/jel.39.4.1101

Kulik, K. S., J., Brewer, H., \& Baker, J. S. (2019). The effect of demographic factors on the implementation of quality physical education. Journal of Physical Education and Sports Management, 6(2), 1 - 13. https://doi.org/10.15640/jpesm.v6n2a1

Labi, A. (2007). Experts assess consequences of global surge in demand for higher education. https://www.chronicle.com/article/experts-assess-consequences-of-globalsurge-in-demand-for-higher-education-47357/

Li, D., Wong, G., \& Boumil, M. (2020). Quality measures in undergraduate medical education. Quality Measures, 151-164. https://doi.org/10.1007/978-3-030-371456_10

Martino, L., Elvira, V., \& Louzada, F. (2017). Effective sample size for importance sampling based on discrepancy measures. Signal Processing, 131, 386-401. https://doi.org/10.1016/j.sigpro.2016.08.025

Mwanga, E. (2015). Determinants of quality education provided at secondary school level: Case of Songea municipal council [Dissertation, Mzumbe University]. http://scholar.mzumbe.ac.tz/bitstream/handle/11192/1121/MSc_A\&F_Mwan ga\%20Elly_2015.pdf?sequence=1.

Ngoc, N. T. M., \& Hawkins, J. N. (2018). Challenges of massification in higher education: The case of Vietnam. Higher Education in Asia: Quality, Excellence and Governance, 103-112. https://doi.org/10.1007/978-981-13-0248-0_8

Nwankwo, S. I. (2013). Customer relationship management and customer retention: Empirical assessment from Nigeria's insurance industry. Business and Economics Journal, 04(02). https:// doi.org/10.4172/2151-6219.1000081

Potter-Brotman, J. (1994). The new role of service in customer retention. Managing service Quality. An International Journal, 4(4), 53-56. https://doi.org/10.1108/09604529410065298

Rahman, M. M. (2013). Quality higher education and students' perception: A study on private universities of Bangladesh. Global Disclosure of Economics and Business, 2(1), 9-19. https://doi.org/10.18034/gdeb.v2i1.190

Sá, C. (2019). Economic determinants of higher education demand. Encyclopedia of International Higher Education Systems and Institutions, 1-6. https://doi.org/10.1007/978-94-017-9553-1_98-1

Sanjay, S., \& Govender, K. (2018). South Africa university students' perceptions of key education service quality determinants. Problems and Perspectives in Management, 16(3), 377-388. https://doi.org/10.21511/ppm.16(3).2018.30 
Sayer, P. (2011). Interviews in qualitative research by King, Nigel, \& Christine Horrocks. The Modern Language Journal, 95(4), 670-671. https://doi.org/10.1111/i.15404781.2011.0154.x

Schargel, F. P. (1996). Why we need total quality management in education. Total Quality Management, 7(2), 213-218. https:// doi.org/10.1080/09544129650034963

Stephens, J. C., Hernandez, M. E., Román, M., Graham, A. C., \& Scholz, R. W. (2008). Higher education as a change agent for sustainability in different cultures and contexts. International Journal of Sustainability in High Education, 9(3), 317-338. https://doi.org/10.1108/14676370810885916

Understanding Research Interviews. (2015). Conducting research interviews for business and management students, 9-24. https://doi.org/10.4135/9781529716726.n2

Wallisch, P., \& Cachia, J. (2019). Determinants of perceived teaching quality: The role of divergent interpretations of expectations. https://doi.org/10.31234/osf.io/dsvgq

Zameer, H., Tara, A., Kausar, U., \& Mohsin, A. (2015). Impact of service quality, corporate image and customer satisfaction towards customers' perceived value in the banking sector in Pakistan. International Journal of Bank Marketing, 33(4), 442-456. https://doi.org/10.1108/ijbm-01-2014-0015

Zeithaml, V. A., Berry, L. L., \& Parasuraman, A. (1993). The nature and determinants of customer expectations of service. Journal of the Academy of Marketing Science, 21(1), 1-12. https:// doi.org/10.1177/0092070393211001

\section{Appendix 1}

\section{STUDENT QUESTIONNAIRE}

The purpose of this study is to investigate determinants of perceived quality education delivery in some selected public universities in Ghana. I assure you of confidentiality and anonymity. Therefore, kindly provide honest responses to these questions as possible as you can by ticking the spaces provided. It will take you about 8 minutes to complete the questionnaire.

\section{SECTION A: Respondents' Profile}

1. University: UCC [ ] UEW [ ] UG [ ]

2. Programme of study: Bed. Soc Sci [ ] Bed. Business [ ] Bed. Arts [ ] Other, specify [ ]

3. Gender: Male: [ ] Female [ ]

4. Age:

\section{SECTION B: Learning Context of Students}

Tick the right box reflecting your opinion on the issues on the learning context of students

1. What is your opinion about the current number of students enrolled in your programme?

Below 20 [ ] students $21-50$ [ ] students 51 and above [ ]

2. What, in your view is the student-staff ratio in the programme you pursue in this university?

$27: 1$ [ ] 28-80:1 [ ] 81 above is to 1 [ ]

3. How would you describe the ratio relative to the programme you are pursuing?

Low [ ] Moderate [ ] High [ ] 
4. How would you describe personality of the teaching staff in your programme?

Boring [ ] Egotistical [ ] Creative [ ] Affectionate [ ]

[Boring: one who is not interesting; Egotistical: acting as if one is more

important than others; Creative: original thinker and one with artistic skills;

Affectionate: one who is very loving]

5. How would you describe the academic content of the programme you are studying currently in your university?

Not satisfactory [ ] Satisfactory [ ] Very Satisfactory [ ]

6. How would you describe the needed job-market career skills being imparted unto you now?

Not satisfactory [ ] Satisfactory [ ] very Satisfactory [ ]

7. How would you describe the useful life skills that are being imparted unto you now necessary for post-higher-education life your university?

Not satisfactory [ ] Satisfactory [ ] very Satisfactory [ ]

8. How do you perceive the service quality provided by the administrative units: the registrar's office, library, faculty office, HoD's/Dean's office, hall master, sports, and university hospital?

Not satisfactory [ ] Satisfactory [ ] very Satisfactory [ ]

\section{SECTION C: Perceived Quality Education Delivery}

Tick in the right box reflecting your opinion about factors affecting the quality delivery of education

\begin{tabular}{|c|c|c|c|c|c|c|c|c|c|}
\hline \multicolumn{6}{|c|}{ Highly Disagree } & \multicolumn{4}{|c|}{ Highly Agree } \\
\hline & 1 & 2 & 3 & 4 & 5 & 6 & 7 & 8 & 9 \\
\hline $\begin{array}{l}\text { Creative and affectionate personality } \\
\text { (teacher personality) of the teaching staff } \\
\text { reflects quality education delivery }\end{array}$ & & & & & & & & & \\
\hline $\begin{array}{l}\text { Boring and egotistic personality (teacher } \\
\text { personality) reflects quality education } \\
\text { delivery reflects quality education delivery }\end{array}$ & & & & & & & & & \\
\hline $\begin{array}{l}\text { Research output (teacher personality) is an } \\
\text { important indicator of quality education } \\
\text { delivery }\end{array}$ & & & & & & & & & \\
\hline $\begin{array}{l}\text { Faculty relationship with students (teacher } \\
\text { personality) reflects quality education } \\
\text { delivery }\end{array}$ & & & & & & & & & \\
\hline $\begin{array}{l}\text { Flexible marks-giving (teacher personality) } \\
\text { reflects quality education delivery }\end{array}$ & & & & & & & & & \\
\hline $\begin{array}{l}\begin{array}{l}\text { Presentation skill of faculty members } \\
\text { (teacher personality) } \\
\text { reflects quality } \\
\text { education delivery. }\end{array} \\
\end{array}$ & & & & & & & & & \\
\hline $\begin{array}{l}\text { Subject-matter knowledge (teacher } \\
\text { personality) of faculty is an important } \\
\text { indicator of quality education delivery }\end{array}$ & & & & & & & & & \\
\hline $\begin{array}{l}\text { Participative teaching methods (teacher } \\
\text { personality) by faculty reflects quality } \\
\text { education delivery }\end{array}$ & & & & & & & & & \\
\hline
\end{tabular}




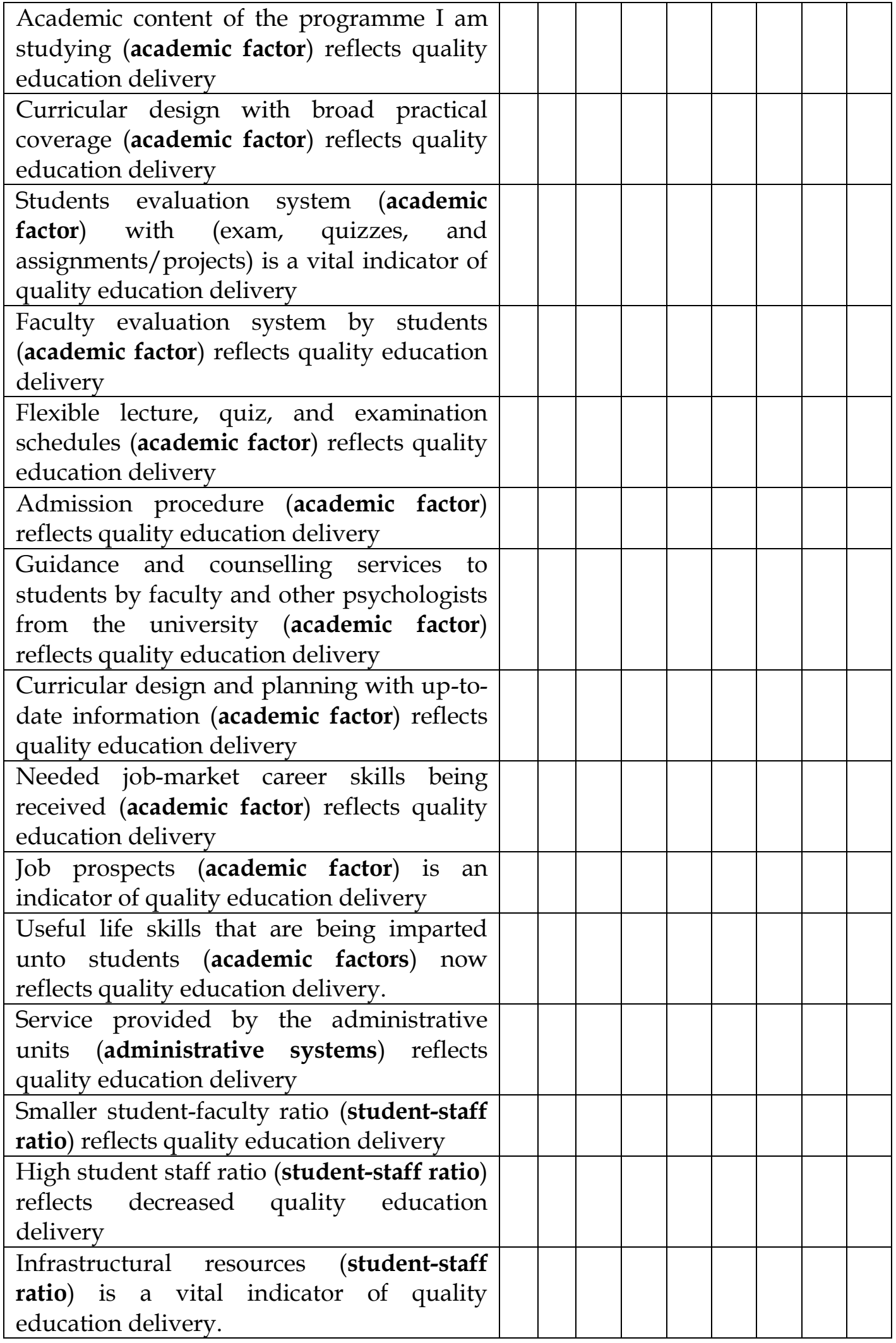

Thank you for the cooperation 
Interview Schedule

\begin{tabular}{|c|c|c|}
\hline $\begin{array}{l}\text { MORNING } \\
\text { INTERVIEW }\end{array}$ & $\begin{array}{l}\text { EVENING } \\
\text { INTERVIEW }\end{array}$ & \\
\hline 8:30 a.m. & 5:00 p.m. & $\begin{array}{l}\text { - Candidates Report on zoom platform } \\
\text { - Meeting with interviewer online }\end{array}$ \\
\hline 8:50 a.m. & 5:20 p.m. & $\begin{array}{ll}\text { - } & \text { Receives briefing on interview } \\
\text { - } & \text { Uses } 20 \text { minutes to prepare responses. }\end{array}$ \\
\hline $\begin{array}{l}\text { 9:00 a.m. - 9:30 } \\
\text { am } \\
\text { Q \& A } \\
\text { [on } \\
\text { respondent's } \\
\text { profile: } \\
\text { university, } \\
\text { programme of } \\
\text { study, gender, } \\
\text { age] } \\
\text { [Learning } \\
\text { Context of } \\
\text { students: their } \\
\text { opinion about } \\
\text { the current } \\
\text { number } \\
\text { students of } \\
\text { enrolled in your } \\
\text { programme, } \\
\text { their view on } \\
\text { the student-staff } \\
\text { ratio in their } \\
\text { university, } \\
\text { (whether low, } \\
\text { moderate or } \\
\text { high and why } \\
\text { they think so), } \\
\text { their description } \\
\text { of personality of } \\
\text { the teaching } \\
\text { staff (whether } \\
\text { they think they } \\
\text { are boring, } \\
\text { egoistical, } \\
\text { creative, } \\
\text { or or }\end{array}$ & $\begin{array}{l}\text { 5:30 p.m. - 6:00 } \\
\text { am } \\
\text { Q \& A } \\
\text { [on } \\
\text { respondent's } \\
\text { profile: } \\
\text { university, } \\
\text { programme of } \\
\text { study, gender, } \\
\text { age] } \\
\text { Learning } \\
\text { Context of } \\
\text { students: their } \\
\text { opinion about } \\
\text { the current } \\
\text { number } \\
\text { students of } \\
\text { enrolled in your } \\
\text { programme, } \\
\text { their view on } \\
\text { the student-staff } \\
\text { ratio in their } \\
\text { university, } \\
\text { (whether low, } \\
\text { moderate or } \\
\text { high and why } \\
\text { they think so), } \\
\text { their description } \\
\text { of personality of } \\
\text { the teaching } \\
\text { staff (whether } \\
\text { they think they } \\
\text { are boring, } \\
\text { egoistical, } \\
\text { creative, }\end{array}$ & $\begin{array}{l}\text { - Interviewer introduces self and strikes } \\
\text { acquaintances with respondents } \\
\text { - Commences with interview questions } \\
\text { - Questions \& Answer Time } \\
\text { - What questions: } \\
\text { current number of students enrolled in } \\
\text { your programme? } \\
\text { - What are your views on the student- } \\
\text { staff ratio in your university? (whether } \\
\text { low, moderate or high and why they } \\
\text { think so), } \\
\text { - How will you describe the personality } \\
\text { of the teaching staff in your university? } \\
\text { Do you see them as (whether they } \\
\text { think they are boring, egoistical, } \\
\text { creative, or affectionate? } \\
\text { How would you describe the academic } \\
\text { content of the programme you are } \\
\text { studying currently in your university? } \\
\text { (Not satisfactory, Satisfactory, Very } \\
\text { Satisfactory) why do you say so? } \\
\text { - How would you describe the needed } \\
\text { job-market career skills being imparted } \\
\text { unto you now? } \\
\text { satisfactory/Satisfactory) and why? } \\
\text { How would you describe the useful life } \\
\text { skills that are being imparted unto you } \\
\text { that are necessary for post-higher- } \\
\text { education life your university? } \\
\text { (satisfactory or not satisfactory and } \\
\text { why? } \\
\text { How do you perceive the service } \\
\text { uuality provided by the administrative } \\
\text { units: the registrar's office, library, } \\
\text { faculty office, HoD's/Dean's office, }\end{array}$ \\
\hline
\end{tabular}




\begin{tabular}{|c|c|c|}
\hline $\begin{array}{l}\text { affectionate). } \\
\text { Interviewer will } \\
\text { break the terms } \\
\text { for them to help } \\
\text { hem respond } \\
\text { properly. For } \\
\text { example a } \\
\text { boring person is } \\
\text { one who is not } \\
\text { interesting; } \\
\text { egotistical is one } \\
\text { who acts as if } \\
\text { one is more } \\
\text { important than } \\
\text { others; creative } \\
\text { person is one } \\
\text { who is an } \\
\text { original thinker } \\
\text { and one with } \\
\text { artistic skills; } \\
\text { and an } \\
\text { Affectionate } \\
\text { person is one } \\
\text { who is very } \\
\text { loving }\end{array}$ & $\begin{array}{l}\text { affectionate). } \\
\text { Interviewer will } \\
\text { break the terms } \\
\text { for them to help } \\
\text { hem respond } \\
\text { properly. For } \\
\text { example a } \\
\text { boring person is } \\
\text { one who is not } \\
\text { interesting; } \\
\text { egotistical is one } \\
\text { who acts as if } \\
\text { one is more } \\
\text { important than } \\
\text { others; creative } \\
\text { person is one } \\
\text { who is an } \\
\text { original thinker } \\
\text { and one with } \\
\text { artistic skills; } \\
\text { and an } \\
\text { Affectionate } \\
\text { person is one } \\
\text { who is very } \\
\text { loving }\end{array}$ & $\begin{array}{l}\text { hall master, sports, and university } \\
\text { hospital? and why? } \\
\text { - Would you say the affectionate } \\
\text { personality of the teaching staff reflects } \\
\text { quality education delivery? } \\
\text { - Does boring and egotistic personality } \\
\text { of the teaching staff, for you, determine } \\
\text { quality education delivery? } \\
\text { - Is research output of the teaching staff } \\
\text { an indicator of quality education } \\
\text { delivery? Why? Etc. } \\
\text { - To you, what other factors determine } \\
\text { quality education and why? }\end{array}$ \\
\hline
\end{tabular}

